\title{
Nedd4-2 regulation of voltage-gated ion channels: an update on structure-function relationships and the pathophysiological consequences of dysfunction
}

\author{
This article was published in the following Dove Press journal: \\ Journal of Receptor, Ligand and Channel Research \\ 18 August 2015 \\ Number of times this article has been viewed
}

\author{
Juan Carlos Arévalo ${ }^{1,2}$ \\ 'Department of Cell Biology and \\ Pathology, Instituto de Neurociencias \\ de Castilla y León, Universidad de \\ Salamanca, ${ }^{2}$ Institute of Biomedical \\ Research of Salamanca, Salamanca, \\ Spain
}

\begin{abstract}
Neuronal excitability is mediated mainly by voltage-gated ion channels (VGICs), which include voltage-gated $\mathrm{Na}^{+}, \mathrm{K}^{+}$, and $\mathrm{Cl}^{-}$channels located along the axon and at neuronal synapses. Voltage-gated channels play pivotal roles in the proper functioning of the nervous system because they set the resting membrane potential, initiate and propagate action potentials, and regulate neurotransmitter release. The abnormal activity or misregulation of VGICs caused by mutations has been directly linked to neurological and cardiac diseases. Among other posttranslational modifications, the ubiquitination of VGICs is a key to the regulation of the number of channels in the cell surface, and hence, neuronal excitability. Nedd4-2 is an E3 ubiquitin ligase that ubiquitinates several proteins, including different VGICs. Accordingly, understanding the molecular mechanisms underlying channel regulation will provide insights to design drugs to treat illnesses. The focus of the present review is to provide an update about the regulation of VGICs upon ubiquitination by Nedd4-2 and the relevance of such regulation in the pathophysiological consequences of dysfunction.
\end{abstract}

Keywords: Nedd4-2, voltage-gated ion channels, disease

\section{Introduction}

The degradation of a protein is as crucial as its synthesis since it ensures the elimination of proteins that participate in different cellular functions. If this does not occur, an unwanted protein will be accumulated, and this will consequently lead to functional disorders. In certain cancers, oncogenic targets are mutated such that they are no longer ubiquitinated; thus, they escape degradation and accumulate in the cell. In the nervous system, correct degradation ensures cell-surface protein turnover and substrate delivery to the proteolytic machineries that are required for both synaptic plasticity and self-renewal, ${ }^{1}$ while abnormal protein accumulation could lead to chronic neurodegenerative processes, such as Alzheimer's disease, Parkinson's disease, Lewy body dementia, and amyotrophic lateral sclerosis. ${ }^{2}$ Voltage-gated ion channels (VGICs) are subject to different posttranslational modifications that regulate their function and stability. Among them, ubiquitination is a key in regulating VGIC protein levels and insertion into the plasma membrane, and alterations in VGICs are therefore associated with different pathologies. Understanding the mechanisms regulating VGICs will be crucial to develop treatments for several pathophysiological dysfunctions in which they have been implicated directly. The present review aims to provide an update of the regulation of different VGICs that are substrates of Nedd4-2, an E3 ubiquitin ligase
Correspondence: Juan Carlos Arévalo C/Pintor Fernando Gallego, I, INCyL-Universidad de Salamanca, 37007 Salamanca, Spain Email arevalojc@usal.es 
belonging to the Homologous to E6AP Carboxy Terminus (HECT) family, and the diseases linked to these channels.

\section{Voltage-gated ion channels}

VGICs are proteins expressed in electrically responsive cells that allow the movement of ions across the cell membrane and that are regulated by the voltage difference across the membrane they span. Among their functions are the initiation and propagation of action potentials, setting the resting membrane potential, and responding to the electrical signals that regulate neurotransmitter release and muscle contraction. The first indication of the existence of VGICs was proposed in the late 1940s by Alan Lloyd Hodgkin and Andrew Fielding Huxley using voltage clamp techniques. They demonstrated that changes in the permeability of $\mathrm{Na}^{+}$ and $\mathrm{K}^{+}$were both necessary and sufficient to produce action potentials and that membrane potential-evoked ionic currents flow across the membrane. ${ }^{3}$ In response to a change to a level more positive than the resting membrane potential in neurons, a redistribution of charge across the axonal membrane occurs; this is caused by two effects: an early, fast and transient inward current of $\mathrm{Na}^{+}$, and a delayed, slow, and sustained outward current of $\mathrm{K}^{+}$.

There are several classes of VGICs that include voltagegated $\mathrm{Na}^{+}, \mathrm{K}^{+}$, and $\mathrm{Cl}^{-}$channels. VGICs are composed of several transmembrane-spanning domains, assembled to form a central ion pore, and a C-terminal tail, which includes different domains and motifs involved in the interaction with different proteins that regulate their insertion in the cell membrane. ${ }^{4-6}$ The number of VGICs present in the membrane is critical for maintaining normal patterns of excitability and is regulated by the rate of insertion, retention, and endocytosis, which are modulated by different conditions and proteins (Figure 1). Mutations in VGICs affecting any of the above processes have been directly implicated in different neurological diseases, such as epilepsy and neuropathic pain, and also in several cardiac diseases.

\section{Voltage-gated sodium channels}

One family of VGICs is the voltage-gated sodium $\left(\mathrm{Na}_{\mathrm{v}}\right)$ channel. $\mathrm{Na}_{\mathrm{v}}$ channels are present in many electrically active tissues, including neurons and both cardiac and skeletal muscle cells, ${ }^{7}$ allowing sodium to flow from the extracellular solution into the cytosol, and consequently causing a depolarization of the cell. $\mathrm{Na}_{\mathrm{v}}$ channels comprise a family consisting of $\mathrm{Na}_{\mathrm{v}} 1.1$ through $\mathrm{Na}_{\mathrm{v}} 1.9$ channels. ${ }^{7-9} \mathrm{Na}_{\mathrm{v}}$ channels initiate action potentials in neurons, whereas they trigger contraction in skeletal and cardiac muscle cells. In response to an action potential in neurons, $\mathrm{Na}_{\mathrm{v}}$ channels open, allowing a large inward-flowing sodium current, rendering the membrane potential more positive, after which the action potential can propagate to the next segment and trigger another action potential. The depolarization due to sodium influx activates a calcium-signaling cascade, causing contraction in skeletal and cardiac muscle cells that respectively result in body movement or blood pumping.

All the $\mathrm{Na}_{\mathrm{v}}$ channel subtypes share a common structure. ${ }^{7}$ The largest subunit of the sodium channel is the $\alpha$-subunit,

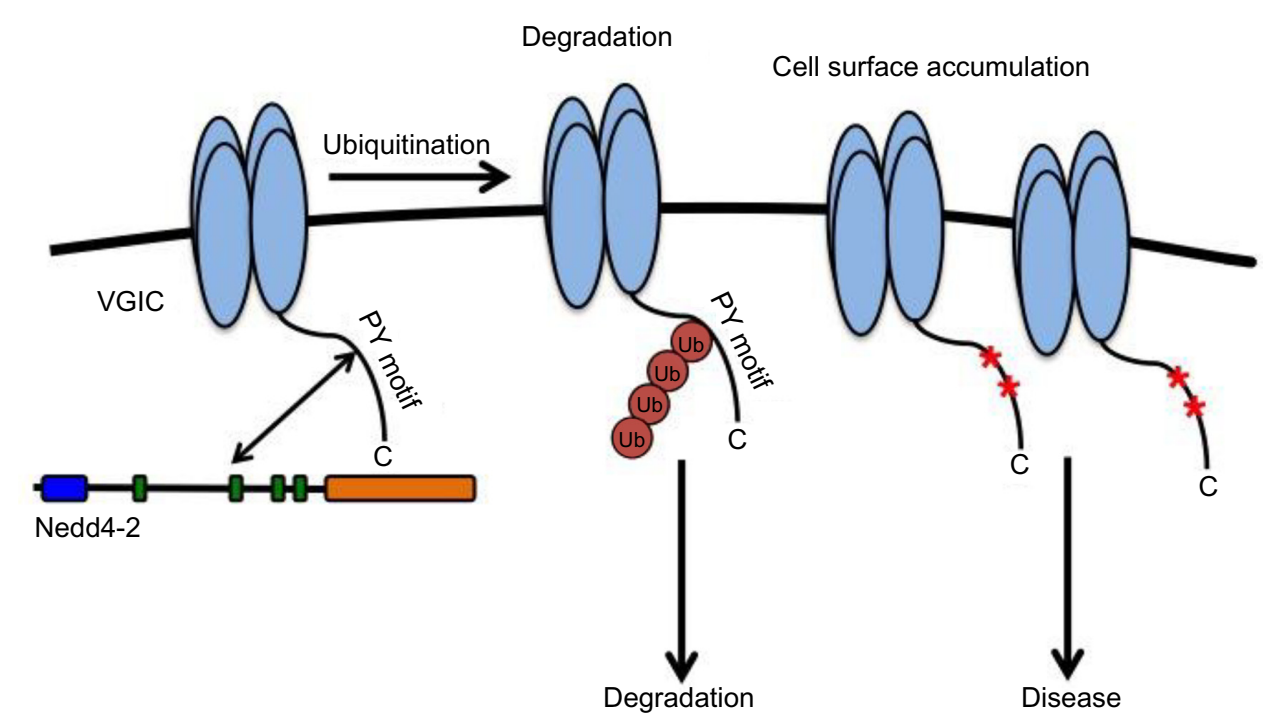

Figure I Nedd4-2 ubiquitinates voltage-gated ion channels.

Notes: Nedd4-2 binds to voltage-gated channels in different ways (PY motifs, other motifs, adaptor proteins with PY motifs, etc) to ubiquitinate and sends them for degradation in response to different stimuli. Mutations in channels affecting Nedd4-2 function accumulate channels at the cell surface, causing different pathologies. Abbreviation: VGIC, voltage-gated ion channel. 
which alone is sufficient to conduct sodium and consists of 24 alpha-helical transmembrane segments arranged in four domains surrounding a central pore. ${ }^{8}$ The first four transmembrane segments of the $\mathrm{Na}_{\mathrm{v}}$ channel form a voltage-sensing domain, and transmembrane segments five and six form a pore domain. The transmembrane segments of the voltagesensing domain and of the pore domain are connected by the extracellular linker (the p-loop), which constitutes the ion selectivity filter for the channel. ${ }^{10}$ In addition, there are smaller beta subunits associated with the channel modulated by them. ${ }^{11}$

Different tissues within the human body predominantly express different $\mathrm{Na}_{\mathrm{v}}$ channel subtypes, whereas $\mathrm{Na}_{\mathrm{v}} 1.1$, $\mathrm{Na}_{\mathrm{v}} 1.2, \mathrm{Na}_{\mathrm{v}} 1.3$, and $\mathrm{Na}_{\mathrm{v}} 1.6$ are mainly expressed in the central nervous system (CNS), $\mathrm{Na}_{\mathrm{v}} 1.7, \mathrm{Na}_{\mathrm{v}} 1.8$, and $\mathrm{Na}_{\mathrm{v}} 1.9$ are found in the peripheral nervous system (PNS). Similarly, $\mathrm{Na}_{\mathrm{v}} 1.4$ is found mostly in skeletal muscle, and $\mathrm{Na}_{\mathrm{v}} 1.5$ is found in cardiac muscle. ${ }^{7,8}$ The expression pattern of different $\mathrm{Na}_{\mathrm{v}}$ channels is highly relevant, since these channels show different voltage dependencies and drug-binding affinities. ${ }^{8,12}$ Accordingly, the differences in the distribution of these channels may have large impacts with regard to the effects of mutations and pharmacological intervention.

\section{Voltage-gated potassium channels}

Voltage-gated $\mathrm{K}^{+}\left(\mathrm{K}_{\mathrm{v}}\right)$ channels are membrane proteins that allow the rapid and selective flow of $\mathrm{K}^{+}$ions out of the cell membrane in order to generate electrical signals in cells. These channels, which are present in all animal cells, open and close with the changes in the transmembrane potential. Together with $\mathrm{Na}_{\mathrm{v}}$ channels, $\mathrm{K}_{\mathrm{v}}$ channels are key components in the generation and propagation of electrical impulses in the nervous system. Following changes in transmembrane potential, these channels open and allow a passive flow of $\mathrm{K}^{+}$ ions from the cell, which restores the membrane potential.

$\mathrm{K}_{\mathrm{v}}$ channels are formed of four subunits arranged symmetrically around the central pore that is formed of transmembrane segments S5-S6 of each subunit. The voltage-sensor domains consist of four transmembrane segments (S1-S4) and are located at the periphery of the channel. ${ }^{13} \mathrm{~A}$ sequence of five amino acids that is highly conserved among potassium channels, voltage-gated or not, is responsible for the high selectivity of the channel. ${ }^{13} \mathrm{~A}$ functional $\mathrm{K}_{\mathrm{v}}$ channel can be formed by either two or four subunits co-assembled as monomers or heteromers, with dimer or tetramer combination displaying a unique set of gating properties. ${ }^{6,14}$

The $\mathrm{K}_{\mathrm{v}}$ channel is the largest family of potassium channels; it includes 40 members and can be classified into
12 subfamilies. ${ }^{6} 15$ In this review, we shall mainly focus on $\mathrm{K}_{\mathrm{v}} 7$ channels since some of them have PY motifs and/or are regulated by Nedd4-2 protein. The $\mathrm{K}_{\mathrm{v}} 7$ channel subfamily is composed of $\mathrm{K}_{\mathrm{v}} 7.1$ (KCNQ1), $\mathrm{K}_{\mathrm{v}} 7.2$ (KCNQ2), $\mathrm{K}_{\mathrm{v}} 7.3$ (KCNQ3), $\mathrm{K}_{\mathrm{v}} 7.4$ (KCNQ4), and $\mathrm{K}_{\mathrm{v}} 7.5$ (KCNQ5). The expression pattern of these channels varies from the heart (KCNQ1) to the nervous system (KCNQ2, KCNQ3, and KCNQ5) and the ear (KCNQ4). ${ }^{16,17}$

\section{Voltage-gated chloride channels}

Chloride channels ( $\mathrm{ClCs}$ ) constitute an evolutionarily wellconserved family of voltage-gated channels that are structurally unrelated to the other known voltage-gated channels, since they function as dimers. They can be classified in bona fide $\mathrm{Cl}^{-}$channels, including $\mathrm{ClC}-1, \mathrm{ClC}-2, \mathrm{ClC}-\mathrm{Ka}$, and $\mathrm{ClC}-$ $\mathrm{Kb}$, and $\mathrm{Cl}^{-} / \mathrm{H}^{+}$antiporters, including $\mathrm{ClC}-3, \mathrm{ClC}-4, \mathrm{ClC}-5$, $\mathrm{ClC}-6$, and $\mathrm{ClC}-7 .{ }^{18} \mathrm{ClCs}$ have been highly conserved along evolution and - among other functions - they regulate cell volume and control electrical excitability and transepithelial transport. They are expressed in several different tissues, some of them having a broad distribution (ClC-2, ClC-3, ClC-4, and ClC-7), while others are more restricted to certain tissues such as skeletal muscle (ClC-1), kidney $(\mathrm{ClC}-\mathrm{Ka} / \mathrm{b}$, $\mathrm{ClC}-5)$, and neuronal tissue (ClC-6). ${ }^{18}$

\section{Ubiquitination and E3 ubiquitin ligases}

Ubiquitination is a posttranslational modification carried out by a set of enzymes to tag ubiquitin, a 76-amino acid polypeptide, to a substrate protein. In this process, ubiquitin is covalently conjugated to the ubiquitin-activating enzyme (E1) in an ATP-dependent manner, after which it is transferred to the ubiquitin-conjugating enzyme (E2), and finally to the substrate protein through the ubiquitin-protein ligase (E3) bridge. ${ }^{19}$ Ubiquitin is bound to a substrate protein through the formation of isopeptide bonds between the $\mathrm{C}$-terminus of ubiquitin and lysine (K) present on substrates. Depending on the number of ubiquitin moieties added to the substrate, there are 1) monoubiquitination, which involves the attachment of a single ubiquitin to a protein; 2) multimonoubiquitination, in which more than one ubiquitin is added to the target protein; and 3) polyubiquitination, in which several moieties of ubiquitin are added in tandem. Since ubiquitin itself contains seven lysine residues (K6, K11, K27, K29, K33, K48, and $\mathrm{K} 63$ ), the conjugated ubiquitin can serve as a substrate for the binding of the next ubiquitin to form a chain. ${ }^{20}$

Protein ubiquitination was first identified as a tag of protein degradation through the proteasome, the substrate 
being labeled with K48 polyubiquitination. ${ }^{19}$ Numerous lines of evidence have also shown that ubiquitin labeling is not always fatal for a protein, since it has been found that monoubiquitination is involved in histone regulation, endocytosis, virus budding, Golgi reassembly, gene transcription, DNA repair, and tumor suppression, ${ }^{21}$ and K63 polyubiquitination contributes to intracellular trafficking. ${ }^{19,22,23}$ Thus, different forms of ubiquitination are related to different fates of the ubiquitinated substrate proteins, and hence, different cell biological functions. This means that protein ubiquitination is a complex process that is still not fully understood.

Regarding the ubiquitination process, much attention has focused on ubiquitin-related enzymes. Interestingly, it has been found that mammalian genomes encode just two E1s, dozens of E2s, but $>500$ E3s. ${ }^{24}$ Moreover, whereas E2s share many well-conserved catalytic domains, E3 ubiquitin ligases share only a few conserved motifs. Therefore, E3 ubiquitin ligases are believed to carry out the important task of recognizing substrate proteins. E3 ubiquitin ligases can be divided into several families based on their structural characteristics, which include 1) the Really Interesting New Gene (RING) family, such as MDM2 and c-Cbl; 2) the HECT family, such as the Neural precursor cell-Expressed Developmentally Down-regulated 4 (Nedd4) family; and 3) the UFD2 homology (U-box) family. ${ }^{25}$ The functional differences between the RING-family and the HECT-family of E3 ubiquitin ligases lie in the fact that RING E3 ubiquitin ligases add ubiquitin carried by E2s directly to the substrates, whereas HECT E3 ubiquitin ligases form a thiol ester intermediate, with ubiquitin transferred first from the E2s and then to the substrate. In addition, HECT E3 ubiquitin ligases play a direct role in catalysis during ubiquitination, whereas RING and U-box E3 ubiquitin ligases facilitate protein ubiquitination. ${ }^{26}$ These latter two E3 ubiquitin ligase types act as adaptor-like molecules by bringing an E2 and a substrate into sufficiently close proximity to promote the ubiquitination of the substrate. While RING-type E3 ubiquitin ligases, such as MDM2 and c-Cbl, can apparently act alone, other E3 ubiquitin ligases are found as components of much larger multi-protein complexes. ${ }^{27}$

\section{Nedd4 E3 ubiquitin ligases}

Nedd4-2 belongs to the Nedd4 family, which in humans includes nine members: Nedd4, Nedd4-2 (Nedd4L), Itch, WWP1, WWP2, SMURF1, SMURF2, Bul1, and NEDL2 (Figure 2). All Nedd4 family members contain a C2 domain in the N-terminus, several WW domains, and a catalytic HECT domain at the C-terminus ${ }^{28}$ (Figure 2). The $\mathrm{C} 2$ domain

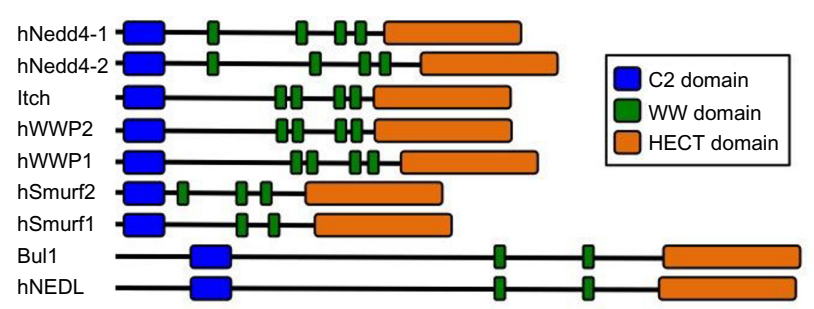

Figure 2 The human Nedd4 family of E3 ubiquitin ligases.

Notes: All Nedd4 protein members are composed of an amino-terminal C2 domain (blue), which is involved in lipid membrane binding, and as a proteinprotein interaction domain, several WW domains (green), which are involved in the interaction with substrates and other proteins, and a carboxy-terminal HECT domain (orange), which is responsible for the catalytic activity.

Abbreviations: HECT, Homologous to E6AP Carboxy Terminus; Nedd4, Neural precursor cell-Expressed Developmentally Down-regulated 4.

translocates the protein to the membrane upon calcium binding, and the WW domains are known to bind substrate proteins containing PY (PPXY) motifs, with lower affinity for LPXY motifs and phosphoserine and phosphothreonine modules. ${ }^{29}$ The catalytic cysteine within the HECT domain is responsible for ubiquitin transfer. ${ }^{30}$ Although there is some redundancy in their functions, it has been demonstrated that different Nedd4 proteins are involved in different biological processes. $^{29}$

Nedd4-2 is the closest homolog of Nedd4, the first member of the HECT family identified. ${ }^{31}$ Nedd4-2 is present in several tissues, but is most highly expressed in heart, kidney, brain, lung, and liver. ${ }^{1,32}$ The first physiological role for Nedd4-2 was its involvement in Liddle's syndrome (an inherited form of hypertension). Mutations that delete or disrupt a C-terminal PY motif in the Epithelial $\mathrm{Na}$ Channel $(\mathrm{ENaC})$, a nonvoltage-gated channel, prevent the interaction of Nedd4-2 with the ENaC, increasing renal $\mathrm{Na}^{+}$absorption and causing Liddle's syndrome. ${ }^{33}$ The ENaC is responsible for salt and fluid reabsorption in the distal nephron, distal colon, and lung epithelia, and abnormal elevations of ENaC activity lead to hypertension. ${ }^{34}$ Nedd4-2 regulates ENaC degradation and activity. It has been found that Nedd4-2 catalyzes both the monoubiquitination and polyubiquitination of ENaC. ${ }^{35}$ The roles of Nedd4-2 in ENaC activity have also been detected in the clearance of lung fluid in newborn animals. Mice knocked out for Nedd4-2 die perinatally, with increased $\mathrm{ENaC}$ expression and activity in the lung, which leads to the failure to inflate the lungs, in turn resulting in the inability of pups to breathe. ${ }^{36,37}$ In addition, Nedd4-2 has been reported to play a protective regulatory role against the development of cystic fibrosis in lung through the regulation of ENaC function. ${ }^{37}$ Other substrates of Nedd4-2 include serum and glucocorticoid kinase (SGK), ${ }^{38} 14-3-3,{ }^{38}$ TrkA, ${ }^{39-43}$ ACK $1,{ }^{44}$ EAAT1/2, ${ }^{45,46}$ Dvl2, ${ }^{47,48}$ etc. For a complete and 
updated list of Nedd4-2-interacting proteins, readers can consult a recent review. ${ }^{49}$ Since the subject of the present review is the regulation of VGIC by Nedd4-2, we shall focus on these substrates.

\section{Regulation of VGICs by Nedd4-2 Voltage-gated sodium channels}

Seven out of the $\mathrm{Na}_{\mathrm{v}}$ channels $\left(\mathrm{Na}_{\mathrm{v}} 1.1, \mathrm{Na}_{\mathrm{v}} 1.2, \mathrm{Na}_{\mathrm{v}} 1.3, \mathrm{Na}_{\mathrm{v}} 1.5\right.$, $\mathrm{Na}_{\mathrm{v}} 1.6, \mathrm{Na}_{\mathrm{v}} 1.7$, and $\mathrm{Na}_{\mathrm{v}} 1.8$ ) include in their $\alpha$-subunit the highly conserved PY motif (L/PPXY) in their C-terminus, recognized by the WW domains of Nedd4-2 (Table 1). Nedd4-2 can bind directly to these channels in vitro and regulate $\mathrm{Na}_{\mathrm{v}}$ currents in different cells. ${ }^{50-52}$ The cardiac $\mathrm{Na}_{\mathrm{v}} 1.5$ was originally reported to be ubiquitinated by Nedd $4,{ }^{53}$ and it has later been extensively investigated in the context of Nedd4$2.52,54 \mathrm{Nedd} 4-2$ expression causes a decrease in $\mathrm{Na}_{\mathrm{v}} 1.5$ current density that depends on the PY motif of the channel and on the catalytic activity of Nedd4-2, leading to the ubiquitination of the channel. ${ }^{52} \mathrm{Na}_{\mathrm{v}} 1.2, \mathrm{Na}_{\mathrm{v}} 1.3, \mathrm{Na}_{\mathrm{v}} 1.6, \mathrm{Na}_{\mathrm{v}} 1.7$, and $\mathrm{Na}_{\mathrm{v}} 1.8$ are also substrates of Nedd4-2 in vitro, ${ }^{28,50,51}$ but the biological significance of the regulation of $\mathrm{Na}_{\mathrm{v}} \mathrm{s}$ by Nedd4-2 has been lacking for many years. Cachemaille et al reported that Nedd4-2 expression was downregulated upon induction of neuropathic pain by the spared nerve injury model, and the authors postulated that this might contribute to the dysregulation of $\mathrm{Na}_{\mathrm{v}} 1.7$ and $\mathrm{Na}_{\mathrm{v}} 1.8$ associated with peripheral nerve injury. ${ }^{55}$ Recently, a seminal work performed by the same group demonstrated that Nedd4-2 indeed regulates the surface expression of $\mathrm{Na}_{\mathrm{v}} 1.7$ and $\mathrm{Na}_{\mathrm{v}} 1.8$ in adult dorsal root ganglion (DRG) neurons in response to neuropathic pain. ${ }^{54}$ Moreover, the levels of $\mathrm{Na}_{\mathrm{v}} 1.7$ and $\mathrm{Na}_{\mathrm{v}} 1.8$ were enhanced in a knockout of Nedd4-2 in nociceptive neurons. These knockout mice showed an altered pain phenotype, suggesting that the regulation of $\mathrm{Na}_{\mathrm{v}} \mathrm{s}$ by Nedd4-2 is critical for the neuronal excitability of the sensory system and that Nedd4-2 downregulation may be required for the central sensitization. ${ }^{54}$ Therefore, Nedd4-2 regulation may be an alternative to $\mathrm{Na}_{v}$ blockers to tackle chronic pain. Regarding the regulation of $\mathrm{Na}_{\mathrm{v}}$ channels in the CNS, it has been shown that Nedd4-2 is essential for the downregulation of the channels in response to elevated intracellular $\mathrm{Na}^{+}$levels in cortical neurons, ${ }^{56}$ although additional work will be necessary to fully understand the role of Nedd4-2 in the CNS.

\section{Voltage-gated potassium channels}

Similar to the effects described for $\mathrm{Na}_{\mathrm{v}} \mathrm{s}$, Nedd4-2 regulates some $\mathrm{K}_{\mathrm{v}}$ s. KCNQ1 has an atypical PY motif (LPXY) in its C-terminus (Table 1) that is well conserved across species and constitutes a binding site for Nedd4-2 and other E3 ubiquitin ligases of the Nedd4 family. The expression of Nedd4-2 in HEK293 cells and cardiomyocytes reduced the amount of KCNQ1 and the current mediated by KCNQ1, respectively. ${ }^{57}$ These effects were dependent on the catalytic activity of Nedd4-2 and on the presence of the PY motif in KCNQ1. ${ }^{57}$ The effect of Nedd4-2 can be counteracted by direct binding of the deubiquitinating enzyme USP2 to KCNQ1 ${ }^{58}$ and by PI3K and SGK1 inhibition of Nedd4-2.59 However, Nedd4-2 activity on KCNQ1 can be induced by adenosine $5^{\prime}$-monophosphate (AMP)-activated protein kinase $(\mathrm{AMPK})^{60}$ and $17 \beta$-oestradiol. ${ }^{61}$

It is now clear that Nedd4-2 regulates heteromeric KCNQ2/3 y KCNQ3/5 channels, although these channels lack the classical PY motif in the C-terminus (Table 1). Nedd4-2 expression decreases the amplitude of the $\mathrm{K}^{+}$ currents mediated by KCNQ2/3 and KCNQ3/5 through a direct interaction with the C-terminus of $\mathrm{KCNQ} 3$ and

Table I Voltage-gated ion channels regulated by Nedd4-2

\begin{tabular}{|c|c|c|c|c|c|c|c|c|c|c|c|c|c|c|c|c|}
\hline \multirow{2}{*}{$\frac{\text { VGIC }}{\mathrm{CIC5}}$} & \multirow{2}{*}{$\begin{array}{l}\text { Function } \\
\text { Chloride ion channel }\end{array}$} & \multirow{2}{*}{$\begin{array}{l}\text { Expression } \\
\text { Kidney/intestine }\end{array}$} & \multicolumn{14}{|c|}{ PY motifs in the C-teminal of VGIC } \\
\hline & & & $E$ & $\mathrm{H}$ & $\mathrm{S}$ & $\mathrm{P}$ & $P$ & $M$ & $\mathbf{P}$ & $\mathbf{P}$ & $\mathbf{Y}$ & $P$ & $P$ & $\mathrm{~T}$ & $\mathrm{~L}$ & K \\
\hline KCNA3 & Voltage-gated potassium channel & Lymphocytes & I & $\mathrm{D}$ & $\mathrm{I}$ & V & A & $\mathrm{I}$ & I & $\mathbf{P}$ & $\mathbf{Y}$ & $\mathrm{F}$ & I & $\mathrm{T}$ & $\mathrm{L}$ & G \\
\hline KCNQI & Voltage-gated potassium channel & Heart/kidney & $\mathrm{L}$ & $P$ & $\mathrm{~S}$ & $\mathrm{~N}$ & $\mathrm{~T}$ & $\mathrm{~L}^{*}$ & $\mathbf{P}$ & $\mathbf{T}$ & $\mathbf{Y}$ & $E$ & $\mathrm{Q}$ & $\mathrm{L}$ & $\mathrm{T}$ & V \\
\hline KCNQ2 & Voltage-gated potassium channel & CNS/PNS & $\mathrm{K}$ & $E$ & $P$ & $\mathrm{E}$ & $P$ & A & $\mathbf{P}$ & $\mathbf{P}$ & $\mathbf{Y}$ & $\mathrm{H}$ & $\mathrm{S}$ & $P$ & $\mathrm{E}$ & $\mathrm{D}$ \\
\hline KCNQ3 & Voltage-gated potassium channel & CNS/PNS & $E$ & $\mathrm{~T}$ & G & $P$ & $P$ & $\mathrm{E}$ & $\mathbf{P}$ & $\mathbf{P}$ & $\mathbf{Y}$ & $\mathrm{S}$ & $\mathrm{F}$ & $\mathrm{H}$ & $Q$ & V \\
\hline $\mathrm{Na}_{v} \mathrm{I} . \mathrm{I}$ & Voltage-gated sodium channel & CNS/PNS & $S$ & $\mathrm{~T}$ & A & $\mathrm{C}$ & C & $\mathbf{P}$ & $\mathbf{P}$ & $\mathbf{S}$ & $\mathbf{Y}$ & $\mathrm{D}$ & $\mathrm{R}$ & V & $\mathrm{T}$ & $\mathrm{K}$ \\
\hline $\mathrm{Na}_{\mathrm{v}} \mathrm{I} .2$ & Voltage-gated sodium channel & CNS & $P$ & $\mathrm{~S}$ & $\mathrm{~T}$ & $\mathrm{~T}$ & $\mathrm{~S}$ & $\mathbf{P}$ & $\mathbf{P}$ & $\mathbf{S}$ & $\mathbf{Y}$ & $\mathrm{D}$ & $\mathrm{S}$ & $\mathrm{V}$ & $\mathrm{T}$ & $\mathrm{K}$ \\
\hline $\mathrm{Na}_{\mathrm{v}} \mathrm{I} .3$ & Voltage-gated sodium channel & CNS & $S$ & $\mathrm{~S}$ & $\mathrm{~T}$ & $\mathrm{~T}$ & $\mathrm{~S}$ & $\mathbf{P}$ & $\mathbf{P}$ & $\mathbf{S}$ & $\mathbf{Y}$ & $\mathrm{D}$ & $\mathrm{S}$ & V & $\mathrm{T}$ & $\mathrm{K}$ \\
\hline $\mathrm{Na}_{\mathrm{v}} \mathrm{I} .5$ & Voltage-gated sodium channel & CNS/heart & $\mathrm{S}$ & $\mathrm{S}$ & $\mathrm{T}$ & $\mathrm{S}$ & $\mathrm{F}$ & $\mathbf{P}$ & $\mathbf{P}$ & $\mathbf{S}$ & $\mathbf{Y}$ & $\mathrm{D}$ & $\mathrm{S}$ & V & $\mathrm{T}$ & $\mathrm{R}$ \\
\hline $\mathrm{Na}_{\mathrm{v}} \mathrm{I} .6$ & Voltage-gated sodium channel & CNS/PNS & $P$ & $\mathrm{~S}$ & $\mathrm{~T}$ & A & $\mathrm{S}$ & $\mathrm{L}^{*}$ & $\mathbf{P}$ & $\mathbf{S}$ & $\mathbf{Y}$ & $\mathrm{D}$ & $S$ & V & $\mathrm{T}$ & $\mathrm{K}$ \\
\hline $\mathrm{Na}{ }_{1} .7$ & Voltage-gated sodium channel & PNS & A & $\mathrm{S}$ & $\mathrm{T}$ & I & $\mathrm{S}$ & $\mathbf{P}$ & $\mathbf{P}$ & $\mathbf{S}$ & $\mathbf{Y}$ & $\mathrm{D}$ & $\mathrm{S}$ & $\mathrm{V}$ & $\mathrm{T}$ & K \\
\hline $\mathrm{Na}{ }^{\prime} .8$ & Voltage-gated sodium channel & PNS & $\mathrm{S}$ & $A$ & $\mathrm{~T}$ & $S$ & $F$ & $\mathbf{P}$ & $\mathbf{P}$ & $\mathbf{S}$ & $\mathbf{Y}$ & $D$ & $S$ & $\mathrm{~V}$ & $\mathrm{~T}$ & $\mathrm{R}$ \\
\hline
\end{tabular}

Notes: PY motif is marked in bold. *Leucine in atypical PY motif.

Abbreviations: VGIC, voltage-gated ion channel; CNS, central nervous system; PNS, peripheral nervous system; CIC, Chloride channel. 
its ubiquitination. ${ }^{62}$ However, the binding motif of KCNQ2 and KCNQ3 recognized by Nedd4-2 remains unknown. Likewise, the peak $\mathrm{K}^{+}$current amplitude of $\mathrm{K}_{\mathrm{v}} 1.3$, which does not contain a PY motif, is reduced by $50 \%$ by Nedd $4-2$ in Xenopus oocytes. ${ }^{63}$ The effects on KCNQ2, KCNQ3, and $\mathrm{K}_{\mathrm{v}} 1.3$ can be counteracted by the inhibition of Nedd4-2 by SGK1. ${ }^{63,64}$ Accordingly, together these in vitro studies suggest that Nedd4-2 regulates $\mathrm{K}_{\mathrm{v}}$ channel surface expression, controlling cell excitability. Future work should validate these results in vivo using genetically modified animals.

\section{Voltage-gated chloride channels}

Among the $\mathrm{Cl}^{-}$channel family, $\mathrm{ClC}-2, \mathrm{ClC}-\mathrm{Ka}$, and $\mathrm{ClC}-\mathrm{Kb}$ have been shown to be regulated by Nedd4-2, ${ }^{65-67}$ although none of these channels contains a PY motif. Upon phosphorylation of Nedd4-2, ClC-2 expression in the plasma membrane is regulated by SGK $1-3 .{ }^{67}$ However, it is unknown whether Nedd4-2 binds directly to $\mathrm{ClC}-2$. To be functional, $\mathrm{ClC}-\mathrm{Ka}$ and $\mathrm{ClC}-\mathrm{Kb}$ channels need an accessory protein, Barttin, containing a PY motif, whose mutation enhances the activity of the $\mathrm{ClC}-\mathrm{Kb}$ /Barttin channel. ${ }^{66}$ In addition, it has been demonstrated that the expression of $\mathrm{ClC}-\mathrm{Ka} /$ Barttin in Xenopus oocytes induces an inwardly rectifying current that is significantly decreased when Nedd4-2, but not the catalytically inactive Nedd4-2C938S, is coexpressed. ${ }^{65}$ The effect of Nedd4-2 can be inhibited by the coexpression of SGK1 or SGK3, due to the phosphorylation of Nedd4-2, which prevents its binding to its target. ${ }^{65} \mathrm{~A}$ mutation of the proline-rich stretch amino acids (PPMPPY) of ClC-5 that resembles the PY motif (Table 1), increases surface expression, ${ }^{68}$ but in vivo disruption of this motif has no effect. ${ }^{69}$ So far, all the reports indicating that Nedd4-2 regulates $\mathrm{ClCs}$ are based on in vitro studies and, therefore, in vivo studies are required to validate previous results.

\section{Regulation of Nedd4-2 function Intramolecular interactions}

Nedd4-2 itself contains a LPPY motif within the HECT that is involved in the interaction with its own WW domains ${ }^{70}$ (Figure 3A). The consequences of this intramolecular interaction are 1) Nedd4-2 autoubiquitination is reduced;2) the stability of Nedd4-2 is increased; and 3) the binding of Nedd4-2 to ENaC is decreased, and this results in increased ENaC activity. ${ }^{70}$ Thus, in basal conditions, the self-interaction of Nedd4-2 seems to protect it from degradation, and it regulates Nedd4-2 interaction with its targets. At present, it is unknown whether the Nedd4-2 intramolecular interaction modulates VGIC levels and functions.

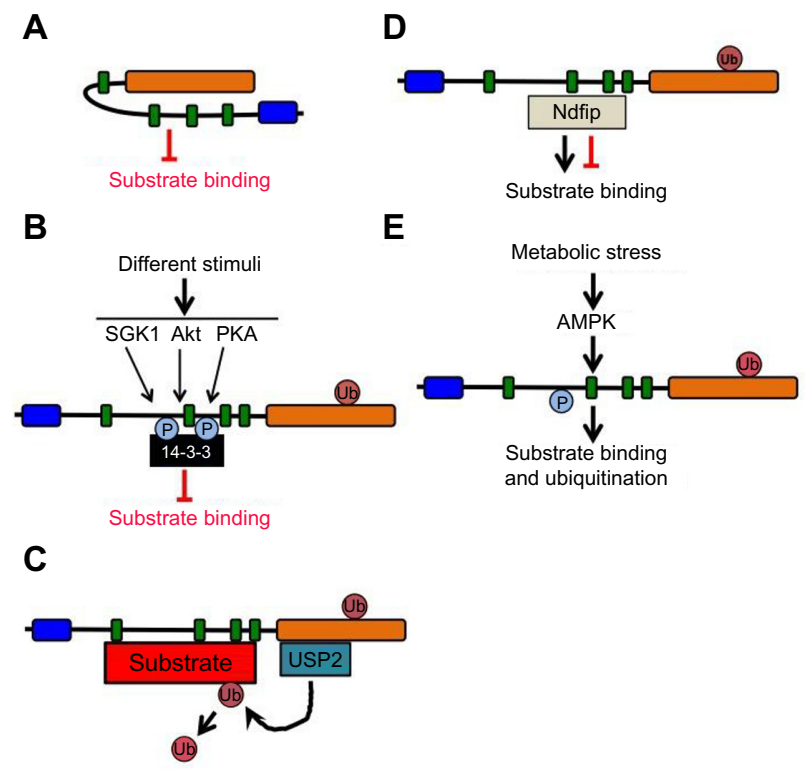

Figure 3 Nedd4-2 activity and binding to substrates can be regulated in several ways.

Notes: (A) Regulation of Nedd4-2 by intramolecular interactions. The binding of the WW domain to the endogenous PY motif inhibits Nedd4-2 activity. (B) Nedd4-2 phosphorylation by SGKs and Akt allows the binding of 14-3-3 proteins, inhibiting Nedd4-2 activity. (C) Nedd4-2 can interact with deubiquitinases that can deubiquitinate different substrates. (D) The binding of Ndfip protein adaptors regulates Nedd4-2 activity. (E) AMPK increases Nedd4-2 activity on its substrates. Abbreviation: AMPK, adenosine 5'-monophosphate (AMP)-activated protein kinase; SGKs, serum and glucocorticoid kinases.

\section{SGKs, Akt, PKA, and I4-3-3 proteins}

Another way by which Nedd4-2 is regulated in response to different stimuli is through phosphorylation by SGK, which decreases the binding of Nedd4-2 and the ubiquitination of $\mathrm{ENaC},{ }^{71} \mathrm{Na}_{\mathrm{v}} 1.5,{ }^{72} \mathrm{ClC}-2,{ }^{67}$ and different membrane transporters $^{45,73,74}$ (Figure 3B). However, SGK1 modulation of ENaC, Kv4.3, EAAT4, or hERG independently of Nedd4-2 phosphorylation has also been reported..$^{75-78}$ The effect of SGK1 in regulating ENaC channels has been suggested previously in SGK1-knockout mice, which had problems in reducing renal $\mathrm{Na}^{+}$output and in maintaining blood pressure under dietary salt restriction. ${ }^{79}$ SGK levels are regulated by Nedd4-2-mediated ubiquitination, ${ }^{80}$ supporting a regulatory loop of both proteins.

However, SGKs are not the only kinases that are able to phosphorylate and inactivate Nedd4-2. Akt and PKA can also phosphorylate and inactivate it ${ }^{81,82}$ (Figure 3B). The residues of Nedd4-2 phosphorylated by the above kinases are binding sites for $14-3-3$ proteins, ${ }^{38,83-85}$ and it is known that this interaction prevents the recruitment of Nedd4-2 to $\mathrm{ENaC}^{84-86}$ (Figure 3B). However, it remains to be addressed whether other substrates of Nedd4-2, such as the VGICs, are regulated by the above kinases and 14-3-3 proteins. 


\section{DUBs}

Another protein that has been demonstrated to regulate Nedd4-2 substrates is the deubiquitinase enzyme USP2, which binds directly to Nedd4-2 and counteracts the effects of Nedd4-2 on $\mathrm{ENaC}^{87}$ and on KCNQ1 $.^{58} \mathrm{Nedd} 4-2$ seems to locate USP2 in close proximity to the ubiquitinated substrates in order to deubiquitinate them (Figure 3C). However, it remains to be seen whether this DUB, or others, may regulate Nedd4-2 activity and/or stability and the effects on other substrates of Nedd4-2.

\section{Ndfip}

As previously indicated, there are substrates of Nedd4-2 that do not contain PY or other motifs that allow the direct binding of the E3 ubiquitin ligase to the substrate. Among Nedd4-2 targets, $\mathrm{ClC}-\mathrm{Ka} / \mathrm{b}$ uses Barttin as a protein adaptor to bring Nedd4-2 close enough to allow ubiquitination. ${ }^{66}$ Other proteins that have been identified as interacting with Nedd4-2, allowing or competing with the binding to different substrates, are the Ndfips (Ndfip1 and Ndfip2). ${ }^{88-90}$ These adaptors can prevent the effect of Nedd4-2 on different substrates such as $\mathrm{ENaC}^{89}$ and EGFR, ${ }^{91}$ whereas they can promote the Nedd4-2-mediated degradation of the divalent metal transporter 1 (DMT1) ${ }^{92}$ and water-channel aquaporin 2 (AQP2) ${ }^{93}$ (Figure 3D). It has been described that Ndfip1 is upregulated in ischemic conditions, and it has been suggested that Ndfip1, together with Nedd4-2 and Itch, may provide neuroprotection. ${ }^{94,95}$ Moreover, it has been reported that Ndfips recruit Nedd4-2 to exosomes to terminate the actions of Nedd4-2. ${ }^{96}$ Whether Ndfips modulate VGICs protein expression and/or function in nonpathological conditions or in response to injury remains to be addressed.

\section{AMPK}

AMPK is activated by increases in the cytoplasmic AMP/ATP concentration ratio, which corresponds to the cellular energy status, ${ }^{97}$ but can also be further activated by the increase in cytoplasmic $\mathrm{Ca}^{2+}$ even in the absence of metabolic stress. ${ }^{98,99}$ Among many different proteins, AMPK regulates some VGICs, including KCNQ1 ${ }^{60,100,101}$ and $\mathrm{Kv} 1.5,{ }^{102}$ not directly but rather by acting through Nedd4-2. In some cases, it has been reported that AMPK phosphorylates Nedd4-2, enhancing the binding to some of its substrates, ${ }^{103}$ and therefore, regulating the ubiquitination of these substrates. However, it is unknown which Nedd4-2 residues are phosphorylated by AMPK, although they must be different from those recognized by 14-3-3 proteins. Identification of the Nedd4-2 amino acids that are phosphorylated by AMPK will provide mechanistic insight regarding the binding and/or activation of Nedd4-2. In addition, it remains to be addressed whether other substrates of Nedd4-2 can be downregulated by AMPK.

\section{Voltage-gated ion channels and disease}

Numerous studies have provided convincing evidence that VGICs play an important role in the functioning of electrical cells and in different pathologies. Mutations in the $\mathrm{Na}_{\mathrm{v}}$ channels expressed in the CNS, such as $\mathrm{Na}_{\mathrm{v}} 1.1$ and $\mathrm{Na}_{\mathrm{v}} 1.2$, cause neurological disorders, including different forms of epilepsy, such as Dravet syndrome (DS), generalized epilepsy with febrile seizure plus, and benign familial neonatal-infantile seizures. ${ }^{104,105}$ These mutations lead to loss of function of $\mathrm{Na}_{\mathrm{v}}$ channels mainly in inhibitory interneurons, thereby impairing their inhibitory function on excitatory neurons and leading to hyperexcitability. ${ }^{106,107}$ Antiepileptic drugs used to control both partial and generalized seizures arising from many different causes may be contraindicated for the treatment of inherited seizure syndromes caused by loss-offunction mutations in $\mathrm{Na}_{\mathrm{v}}$ channels. An alternative approach to rebalance excitation and inhibition is to enhance inhibitory neurotransmission using benzodiazepines that enhance GABA receptors in combination with other drugs. ${ }^{108}$ This has been proved to be a successful strategy in preventing seizures in DS, although most patients are not seizure free. ${ }^{108}$

Mutations of $\mathrm{Na}_{\mathrm{v}}$ expressed in the PNS, mainly $\mathrm{Na}_{\mathrm{v}} 1.7$, cause different kind of pain syndromes. ${ }^{109}$ Gain-of-function mutations are associated with erythromelalgia and paroxysmal extreme pain disorder as a result of sensory neuron hyperexcitability, whereas loss-of-function mutations result in congenital indifference to pain because of an attenuation in action potential firing that causes complete loss of pain sensation. ${ }^{109-111}$ Moreover, mutations in $\mathrm{Na}_{\mathrm{v}}$ cardiac channels, mainly in $\mathrm{Na}_{\mathrm{v}} 1.5$, cause cardiac arrhythmias such as Brugada syndrome, Long QT (LQT) syndrome, ventricular fibrillation, and sudden infant death syndrome. ${ }^{12-114}$ Treatment of LQT syndrome using sodium current blockers, such as mexiletine, flecainide, or ranolazine, may represent a therapeutic option, ${ }^{115,116}$ although the response to the drug is mutation-specific showing benefits in some LQT patients, but not in others.

In addition to the altered functionality of $\mathrm{Na}_{\mathrm{v}}$ due to mutations, regulation of its localization and expression are highly relevant for the development of peripheral neuropathic pain. In a spared nerve injury model, Nedd4-2 expression was decreased in DRG neurons, ${ }^{54,55}$ leading to increased $\mathrm{Na}_{\mathrm{v}} 1.7$ 
and $\mathrm{Na}_{\mathrm{v}} 1.8$ levels that enhanced the currents meditated by these channels. ${ }^{54}$ These results were further confirmed in Nedd4-2 knockout mice, which exhibited increased thermal and inflammatory pain. ${ }^{54}$ Restoration of Nedd4-2 levels in the SNI model eased the mechanical allodynia experienced by these mice. Together, these results point to Nedd4-2 as a key regulator of $\mathrm{Na}_{\mathrm{v}}$ in chronic pain that may be of use as a target to control different pain pathologies. Specific blockers of $\mathrm{Na}_{\mathrm{v}} 1.7, \mathrm{Na}_{\mathrm{v}} 1.8$, and $\mathrm{Na}_{\mathrm{v}} 1.9$ that are currently in development may represent an appropriate drug for the treatment of patients with gain-of-function mutations in these channels.

$\mathrm{K}_{\mathrm{v}}$ channels have been implicated in different pathologies, including LQT syndrome (KCNQ1), deafness (KCNQ1, $\mathrm{KCNQ} 4$ ), and benign familial neonatal seizures (KCNQ2, KCNQ3). ${ }^{117,118}$ The mutations described for these channels can lead to impaired protein stability, misfolding, trafficking, and alterations in channel gating. Some drugs acting on KCNQ channels to modulate their activity are currently being developed as treatments for epilepsy. One of them is retigabine, which stabilizes neuronal KCNQ channels in the open position without affecting cardiac KCNQ1 channels, and therefore, decreasing the potential for cardiac side effects. This drug leads to hyperpolarization of the subthreshold membrane potential by increasing the outward $\mathrm{K}^{+}$current. ${ }^{19-121}$

A number of human disease-causing mutations have been identified in the genes encoding ClCs. Mutations in ClC-1 lead to both recessively- and dominantly inherited forms of muscle stiffness or myotonia. ${ }^{122}$ Mutations in ClC-2 in humans result in leukodystrophy, ${ }^{123}$ whereas mutations in $\mathrm{ClC}-\mathrm{Ka}$ and $\mathrm{ClC}-\mathrm{Kb}$ lead to Bartter syndrome, which combines deafness and a severe renal phenotype. ${ }^{124,125}$ Similarly, mutations in ClC-5 lead to several forms of inherited kidney stone disease named Dent's disease, ${ }^{126,127}$ while other mutations lead only to proteinuria. ${ }^{128}$ These mutations have been shown to reduce or abolish $\mathrm{ClC}$ function.

\section{Conclusion}

VGICs are crucial components for the proper functioning of electrically stimulated cells, and hence, their numbers and presence at the plasma membrane must be tightly controlled. Ubiquitination is a posttranslational modification that regulates protein stability, as well as protein trafficking and localization, and Nedd4-2 ubiquitinates several VGICs and regulates their functions. Misregulation or mutations that change the location or number of the VGICs are the basis of several different neurological and cardiac diseases.
Several questions remain to be answered, and further studies should address the following issues, among others: 1) the identification of other VGICs that are substrates of Nedd4-2; 2) a better understanding of the molecular mechanisms involved in the regulation of VGICs, with the identification of accessory proteins that participate in the ubiquitination of VGICs by Nedd4-2; 3) the role of Nedd4-2 in the development of cardiac diseases with the use of genetically modified mice. The seminal in vivo studies indicating that Nedd4-2 protein levels are regulated in response to chronic pain and that Nedd4-2 modulates $\mathrm{Na}_{\mathrm{v}} 1.7$ and $\mathrm{Na}_{\mathrm{v}} 1.8$ channels in neuropathic pain should also be the basis for future studies. Gaining further knowledge about interactions between VGICs and Nedd4-2 from recent advances in solving structures of transmembrane proteins may also allow the development of drugs that potentiate or block these complexes in a specific manner. Such drugs could be of potential therapeutic use in diseases in which VGICs are involved directly.

\section{Acknowledgments}

The work in my laboratory has been supported by Ministerio de Ciencia e Innovación Grant BFU2008-00162, by Ministerio de Economía y Competitividad Grants BFU201122898 and BFU2014-51846-R, and within the VII European Community Framework Programme by a Marie Curie International Reintegration Grant and by the PAINCAGE integrative project.

\section{Disclosure}

The author reports no conflicts of interest in this work.

\section{References}

1. Araki N, Umemura M, Miyagi Y, et al. Expression, transcription, and possible antagonistic interaction of the human Nedd4L gene variant: implications for essential hypertension. Hypertension. 2008;51(3):773-777.

2. Bedford L, Lowe J, Dick LR, Mayer RJ, Brownell JE. Ubiquitin-like protein conjugation and the ubiquitin-proteasome system as drug targets. Nat Rev Drug Discov. 2011;10(1):29-46.

3. Hodgkin AL, Huxley AF. Currents carried by sodium and potassium ions through the membrane of the giant axon of Loligo. J Physiol. 1952; 116(4):449-472.

4. Catterall WA, Goldin AL, Waxman SG. International Union of Pharmacology. XLVII. Nomenclature and structure-function relationships of voltage-gated sodium channels. Pharmacol Rev. 2005;57(4):397-409.

5. Duran C, Thompson CH, Xiao Q, Hartzell HC. Chloride channels: often enigmatic, rarely predictable. Annu Rev Physiol. 2010;72:95-121.

6. Gutman GA, Chandy KG, Grissmer S, et al. International Union of Pharmacology. LIII. Nomenclature and molecular relationships of voltage-gated potassium channels. Pharmacol Rev. 2005;57(4):473-508.

7. Goldin AL. Diversity of mammalian voltage-gated sodium channels. Ann NY Acad Sci. 1999;868:38-50.

8. Catterall WA, Perez-Reyes E, Snutch TP, Striessnig J. International Union of Pharmacology. XLVIII. Nomenclature and structure-function relationships of voltage-gated calcium channels. Pharmacol Rev. 2005;57(4):411-425. 
9. Watanabe E, Fujikawa A, Matsunaga $\mathrm{H}$, et al. Nav2/NaG channel is involved in control of salt-intake behavior in the CNS. J Neurosci. 2000;20(20):7743-7751.

10. Payandeh J, Scheuer T, Zheng N, Catterall WA. The crystal structure of a voltage-gated sodium channel. Nature. 2011;475(7356):353-358.

11. Egri C, Ruben PC. A hot topic: temperature sensitive sodium channelopathies. Channels. 2012;6(2):75-85.

12. Vilin YY, Peters CH, Ruben PC. Acidosis differentially modulates inactivation in na(v)1.2, na(v)1.4, and na(v)1.5 channels. Front Pharmacol. 2012;3:109.

13. Doyle DA, Morais Cabral J, Pfuetzner RA, et al. The structure of the potassium channel: molecular basis of $\mathrm{K}+$ conduction and selectivity. Science. 1998;280(5360):69-77.

14. Coetzee WA, Amarillo Y, Chiu J, et al. Molecular diversity of K+ channels. Ann NY Acad Sci. 1999;868:233-285.

15. Sharman JL, Mpamhanga CP, Spedding M, et al. IUPHAR-DB: new receptors and tools for easy searching and visualization of pharmacological data. Nucleic Acids Res. 2011;39(Database issue):D534-D538.

16. Jentsch TJ. Neuronal KCNQ potassium channels: physiology and role in disease. Nat Rev Neurosci. 2000;1(1):21-30.

17. Maljevic S, Wuttke TV, Seebohm G, Lerche H. KV7 channelopathies. Pflugers Arch. 2010;460(2):277-288.

18. Jentsch TJ. Discovery of CLC transport proteins: cloning, structure, function and pathophysiology. J Physiol. Epub 2015 Feb 19

19. Hershko A, Ciechanover A, Varshavsky A. Basic medical research award. The ubiquitin system. Nat Med. 2000;6(10):1073-1081.

20. Hershko A, Ciechanover A. The ubiquitin system. Annu Rev Biochem. 1998;67:425-479.

21. Ikeda F, Dikic I. Atypical ubiquitin chains: new molecular signals. 'protein modifications: beyond the usual suspects' review series. EMBO Rep. 2008;9(6):536-542.

22. Mukhopadhyay D, Riezman H. Proteasome-independent functions of ubiquitin in endocytosis and signaling. Science. 2007;315(5809) 201-205.

23. Geetha T, Jiang J, Wooten MW. Lysine 63 polyubiquitination of the nerve growth factor receptor TrkA directs internalization and signaling. Mol Cell. 2005;20(2):301-312.

24. Kawabe H, Brose N. The role of ubiquitylation in nerve cell development. Nat Rev Neurosci. 2011;12(5):251-268.

25. Weissman AM, Shabek N, Ciechanover A. The predator becomes the prey: regulating the ubiquitin system by ubiquitylation and degradation. Nat Rev Mol Cell Biol. 2011;12(9):605-620.

26. Scheffner M, Kumar S. Mammalian HECT ubiquitin-protein ligases biological and pathophysiological aspects. Biochim Biophys Acta 2014;1843(1):61-74.

27. Ardley HC, Robinson PA. E3 ubiquitin ligases. Essays Biochem. 2005;41:15-30.

28. Gasser A, Cheng X, Gilmore ES, Tyrrell L, Waxman SG, Dib-Hajj SD. Two Nedd4-binding motifs underlie modulation of sodium channel Nav1.6 by p38 MAPK. J Biol Chem. 2010;285(34):26149-26161.

29. Yang B, Kumar S. Nedd4 and Nedd4-2: closely related ubiquitinprotein ligases with distinct physiological functions. Cell Death Differ. 2010;17(1):68-77.

30. Chen C, Sun X, Guo P, et al. Ubiquitin E3 ligase WWP1 as an oncogenic factor in human prostate cancer. Oncogene. 2007;26(16):2386-2394.

31. Kumar S, Tomooka Y, Noda M. Identification of a set of genes with developmentally down-regulated expression in the mouse brain. Biochem Biophys Res Commun. 1992;185(3):1155-1161.

32. Kumar S, Harvey KF, Kinoshita M, Copeland NG, Noda M, Jenkins NA. cDNA cloning, expression analysis, and mapping of the mouse Nedd4 gene. Genomics. 1997;40(3):435-443.

33. Knight KK, Olson DR, Zhou R, Snyder PM. Liddle's syndrome mutations increase $\mathrm{Na}+$ transport through dual effects on epithelial $\mathrm{Na}+$ channel surface expression and proteolytic cleavage. Proc Natl Acad Sci US A. 2006;103(8):2805-2808.

34. Hummler E. Implication of $\mathrm{ENaC}$ in salt-sensitive hypertension. J Steroid Biochem Mol Biol. 1999;69(1-6):385-390.
35. Zhou R, Patel SV, Snyder PM. Nedd4-2 catalyzes ubiquitination and degradation of cell surface ENaC. J Biol Chem. 2007;282(28): 20207-20212.

36. Boase NA, Rychkov GY, Townley SL, et al. Respiratory distress and perinatal lethality in Nedd4-2-deficient mice. Nat Commun. 2011;2:287.

37. Kimura T, Kawabe H, Jiang C, et al. Deletion of the ubiquitin ligase Nedd4L in lung epithelia causes cystic fibrosis-like disease. Proc Natl Acad Sci U S A. 2011;108(8):3216-3221.

38. Bhalla V, Daidié D, Li H, et al. Serum- and glucocorticoid-regulated kinase 1 regulates ubiquitin ligase neural precursor cell-expressed, developmentally down-regulated protein 4-2 by inducing interaction with 14-3-3. Mol Endocrinol. 2005;19(12):3073-3084.

39. Arévalo JC, Waite J, Rajagopal R, et al. Cell survival through Trk neurotrophin receptors is differentially regulated by ubiquitination. Neuron. 2006;50(4):549-559.

40. Georgieva MV, de Pablo Y, Sanchis D, Comella JX, Llovera M. Ubiquitination of TrkA by Nedd4-2 regulates receptor lysosomal targeting and mediates receptor signaling. J Neurochem. 2011;117(3): 479-493.

41. Persaud A, Alberts P, Amsen EM, et al. Comparison of substrate specificity of the ubiquitin ligases Nedd4 and Nedd4-2 using proteome arrays. Mol Syst Biol. 2009;5:333.

42. Yu T, Calvo L, Anta B, et al. In vivo regulation of NGF-mediated functions by Nedd4-2 ubiquitination of TrkA. J Neurosci. 2014; 34(17):6098-6106.

43. Yu T, Calvo L, Anta B, et al. Regulation of trafficking of activated TrkA is critical for NGF-mediated functions. Traffic. 2011;12(4):521-534.

44. Chan W, Tian R, Lee YF, Sit ST, Lim L, Manser E. Down-regulation of active ACK1 is mediated by association with the E3 ubiquitin ligase Nedd4-2. J Biol Chem. 2009;284(12):8185-8194.

45. Boehmer C, Henke G, Schniepp R, et al. Regulation of the glutamate transporter EAAT1 by the ubiquitin ligase Nedd4-2 and the serum and glucocorticoid-inducible kinase isoforms SGK1/3 and protein kinase B. J Neurochem. 2003;86(5):1181-1188.

46. Boehmer C, Palmada M, Rajamanickam J, Schniepp R, Amara S, Lang F. Post-translational regulation of EAAT2 function by co-expressed ubiquitin ligase Nedd4-2 is impacted by SGK kinases. $J$ Neurochem. 2006;97(4):911-921.

47. Ding Y, Zhang Y, Xu C, Tao QH, Chen YG. HECT domain-containing E3 ubiquitin ligase NEDD4L negatively regulates Wnt signaling by targeting dishevelled for proteasomal degradation. J Biol Chem. 2013; 288(12):8289-8298.

48. Zhang Y, Ding Y, Chen YG, Tao Q. NEDD4L regulates convergent extension movements in Xenopus embryos via disheveled-mediated non-canonical Wnt signaling. Dev Biol. 2014;392(1):15-25.

49. Goel P, Manning JA, Kumar S. NEDD4-2 (NEDD4L): the ubiquitin ligase for multiple membrane proteins. Gene. 2015;557(1):1-10.

50. Fotia AB, Ekberg J, Adams DJ, Cook DI, Poronnik P, Kumar S. Regulation of neuronal voltage-gated sodium channels by the ubiquitin-protein ligases Nedd4 and Nedd4-2. J Biol Chem. 2004;279(28):28930-28935.

51. Rougier JS, van Bemmelen MX, Bruce MC, et al. Molecular determinants of voltage-gated sodium channel regulation by the Nedd4/Nedd4-like proteins. Am J Physiol Cell Physiol. 2005;288(3):C692-C701.

52. van Bemmelen MX, Rougier JS, Gavillet B, et al. Cardiac voltage-gated sodium channel Nav1.5 is regulated by Nedd4-2 mediated ubiquitination. Circ Res. 2004;95(3):284-291.

53. Abriel H, Kamynina E, Horisberger JD, Staub O. Regulation of the cardiac voltage-gated $\mathrm{Na}+$ channel $(\mathrm{H} 1)$ by the ubiquitin-protein ligase Nedd4. FEBS Lett. 2000;466(2-3):377-380.

54. Laedermann CJ, Cachemaille M, Kirschmann G, et al. Dysregulation of voltage-gated sodium channels by ubiquitin ligase NEDD4-2 in neuropathic pain. J Clin Invest. 2013;123(7):3002-3013.

55. Cachemaille M, Laedermann CJ, Pertin M, Abriel H, Gosselin RD, Decosterd I. Neuronal expression of the ubiquitin ligase Nedd4-2 in rat dorsal root ganglia: modulation in the spared nerve injury model of neuropathic pain. Neuroscience. 2012;227:370-380. 
56. Ekberg JA, Boase NA, Rychkov G, Manning J, Poronnik P, Kumar S. Nedd4-2 (NEDD4L) controls intracellular $\mathrm{Na}(+)$-mediated activity of voltage-gated sodium channels in primary cortical neurons. Biochem J. 2014;457(1):27-31.

57. Jespersen T, Membrez M, Nicolas CS, et al. The KCNQ1 potassium channel is down-regulated by ubiquitylating enzymes of the Nedd4/ Nedd4-like family. Cardiovasc Res. 2007;74(1):64-74.

58. Krzystanek K, Rasmussen HB, Grunnet M, et al. Deubiquitylating enzyme USP2 counteracts Nedd4-2-mediated downregulation of KCNQ1 potassium channels. Heart Rhythm. 2012;9(3):440-448.

59. Andersen MN, Krzystanek K, Petersen F, et al. A phosphoinositide 3-kinase (PI3K)-serum- and glucocorticoid-inducible kinase 1 (SGK1) pathway promotes Kv7.1 channel surface expression by inhibiting Nedd4-2 protein. J Biol Chem. 2013;288(52):36841-36854.

60. Alzamora R, Gong F, Rondanino C, et al. AMP-activated protein kinase inhibits KCNQ1 channels through regulation of the ubiquitin ligase Nedd4-2 in renal epithelial cells. Am J Physiol Renal Physiol. 2010;299(6):F1308-F1319.

61. Rapetti-Mauss R, O’Mahony F, Sepulveda FV, Urbach V, Harvey BJ. Oestrogen promotes KCNQ1 potassium channel endocytosis and postendocytic trafficking in colonic epithelium. J Physiol. 2013;591 (pt 11):2813-2831.

62. Ekberg J, Schuetz F, Boase NA, et al. Regulation of the voltage-gated $\mathrm{K}(+)$ channels KCNQ2/3 and KCNQ3/5 by ubiquitination. Novel role for Nedd4-2. J Biol Chem. 2007;282(16):12135-12142.

63. Henke G, Maier G, Wallisch S, Boehmer C, Lang F. Regulation of the voltage gated $\mathrm{K}+$ channel Kv1.3 by the ubiquitin ligase Nedd4-2 and the serum and glucocorticoid inducible kinase SGK1. J Cell Physiol. 2004;199(2):194-199.

64. Schuetz F, Kumar S, Poronnik P, Adams DJ. Regulation of the voltage-gated $\mathrm{K}(+)$ channels $\mathrm{KCNQ} 2 / 3$ and $\mathrm{KCNQ} 3 / 5$ by serumand glucocorticoid-regulated kinase-1. Am J Physiol Cell Physiol. 2008;295(1):C73-C80.

65. Embark HM, Böhmer C, Palmada M, et al. Regulation of CLC-Ka/barttin by the ubiquitin ligase Nedd4-2 and the serum- and glucocorticoiddependent kinases. Kidney Int. 2004;66(5):1918-1925.

66. Estévez R, Boettger T, Stein V, et al. Barttin is a Cl-channel beta-subunit crucial for renal Cl-reabsorption and inner ear $\mathrm{K}+$ secretion. Nature. 2001;414(6863):558-561.

67. Palmada M, Dieter M, Boehmer C, Waldegger S, Lang F. Serum and glucocorticoid inducible kinases functionally regulate ClC-2 channels. Biochem Biophys Res Commun. 2004;321(4):1001-1006.

68. Schwake M, Friedrich T, Jentsch TJ. An internalization signal in ClC-5, an endosomal Cl-channel mutated in Dent's disease. J Biol Chem. 2001; 276(15):12049-12054.

69. Rickheit G, Wartosch L, Schaffer S, et al. Role of ClC-5 in renal endocytosis is unique among $\mathrm{ClC}$ exchangers and does not require PY-motifdependent ubiquitylation. J Biol Chem. 2010;285(23):17595-17603.

70. Bruce MC, Kanelis V, Fouladkou F, Debonneville A, Staub O, Rotin D. Regulation of Nedd4-2 self-ubiquitination and stability by a PY motif located within its HECT-domain. Biochem J. 2008;415(1):155-163.

71. Snyder PM, Olson DR, Thomas BC. Serum and glucocorticoid-regulated kinase modulates Nedd4-2-mediated inhibition of the epithelial $\mathrm{Na}+$ channel. J Biol Chem. 2002;277(1):5-8.

72. Boehmer C, Wilhelm V, Palmada M, et al. Serum and glucocorticoid inducible kinases in the regulation of the cardiac sodium channel SCN5A. Cardiovasc Res. 2003;57(4):1079-1084.

73. Boehmer C, Embark HM, Bauer A, et al. Stimulation of renal Na+dicarboxylate cotransporter 1 by $\mathrm{Na}+\mathrm{H}+$ exchanger regulating factor 2 , serum and glucocorticoid inducible kinase isoforms, and protein kinase B. Biochem Biophys Res Commun. 2004;313(4):998-1003.

74. Dieter M, Palmada M, Rajamanickam J, et al. Regulation of glucose transporter SGLT1 by ubiquitin ligase Nedd4-2 and kinases SGK1, SGK3, and PKB. Obes Res. 2004;12(5):862-870.

75. Baltaev R, Strutz-Seebohm N, Korniychuk G, Myssina S, Lang F, Seebohm G. Regulation of cardiac shal-related potassium channel Kv 4.3 by serum- and glucocorticoid-inducible kinase isoforms in Xenopus oocytes. Pflugers Arch. 2005;450(1):26-33.
76. Diakov A, Korbmacher C. A novel pathway of epithelial sodium channel activation involves a serum- and glucocorticoid-inducible kinase consensus motif in the $\mathrm{C}$ terminus of the channel's alpha-subunit. J Biol Chem. 2004;279(37):38134-38142.

77. Lamothe SM, Zhang S. The serum- and glucocorticoid-inducible kinases SGK1 and SGK3 regulate hERG channel expression via ubiquitin ligase Nedd4-2 and GTPase Rab11. J Biol Chem. 2013;288(21): 15075-15084

78. Rajamanickam J, Palmada M, Lang F, Boehmer C. EAAT4 phosphorylation at the SGK1 consensus site is required for transport modulation by the kinase. J Neurochem. 2007;102(3):858-866.

79. Lang F, Henke G, Embark HM, et al. Regulation of channels by the serum and glucocorticoid-inducible kinase - implications for transport, excitability and cell proliferation. Cell Physiol Biochem. 2003;13(1): $41-50$.

80. Zhou R, Snyder PM. Nedd4-2 phosphorylation induces serum and glucocorticoid-regulated kinase (SGK) ubiquitination and degradation. J Biol Chem. 2005;280(6):4518-4523.

81. Ismail NA, Baines DL, Wilson SM. The phosphorylation of endogenous Nedd4-2 In $\mathrm{Na}(+)$-absorbing human airway epithelial cells. Eur J Pharmacol. 2014;732:32-42.

82. Lee IH, Dinudom A, Sanchez-Perez A, Kumar S, Cook DI. Akt mediates the effect of insulin on epithelial sodium channels by inhibiting Nedd4-2. J Biol Chem. 2007;282(41):29866-29873.

83. Chandran S, Li H, Dong W, et al. Neural precursor cell-expressed developmentally down-regulated protein 4-2 (Nedd4-2) regulation by 14-3-3 protein binding at canonical serum and glucocorticoid kinase 1 (SGK1) phosphorylation sites. J Biol Chem. 2011;286(43):37830-37840.

84. Ichimura T, Yamamura H, Sasamoto K, et al. 14-3-3 Proteins modulate the expression of epithelial $\mathrm{Na}+$ channels by phosphorylationdependent interaction with Nedd4-2 ubiquitin ligase. J Biol Chem. 2005;280(13):13187-13194.

85. Liang X, Butterworth MB, Peters KW, Walker WH, Frizzell RA. An obligatory heterodimer of 14-3-3beta and 14-3-3epsilon is required for aldosterone regulation of the epithelial sodium channel. $J$ Biol Chem. 2008;283(41):27418-27425.

86. Nagaki K, Yamamura H, Shimada S, et al. 14-3-3 Mediates phosphorylation-dependent inhibition of the interaction between the ubiquitin E3 ligase Nedd4-2 and epithelial $\mathrm{Na}+$ channels. Biochemistry. 2006;45(21):6733-6740.

87. Oberfeld B, Ruffieux-Daidie D, Vitagliano JJ, Pos KM, Verrey F, Staub O. Ubiquitin-specific protease 2-45 (Usp2-45) binds to epithelial $\mathrm{Na}+$ channel (ENaC)-ubiquitylating enzyme Nedd4-2. Am J Physiol Renal Physiol. 2011;301(1):F189-F196.

88. Harvey KF, Shearwin-Whyatt LM, Fotia A, Parton RG, Kumar S. N4WBP5, a potential target for ubiquitination by the Nedd4 family of proteins, is a novel Golgi-associated protein. J Biol Chem. 2002; 277(11):9307-9317.

89. Konstas AA, Shearwin-Whyatt LM, Fotia AB, et al. Regulation of the epithelial sodium channel by N4WBP5A, a novel Nedd4/Nedd4-2interacting protein. J Biol Chem. 2002;277(33):29406-29416.

90. Mund T, Pelham HR. Control of the activity of WW-HECT domain E3 ubiquitin ligases by NDFIP proteins. EMBO Rep. 2009;10(5): 501-507.

91. Shearwin-Whyatt LM, Brown DL, Wylie FG, Stow JL, Kumar S. N4WBP5A (Ndfip2), a Nedd4-interacting protein, localizes to multivesicular bodies and the Golgi, and has a potential role in protein trafficking. J Cell Sci. 2004;117(pt 16):3679-3689.

92. Howitt J, Putz U, Lackovic J, et al. Divalent metal transporter 1 (DMT1) regulation by Ndfip1 prevents metal toxicity in human neurons. Proc Natl Acad Sci U S A. 2009;106(36):15489-15494.

93. Velic A, Gabriëls G, Hirsch JR, et al. Acute rejection after rat renal transplantation leads to downregulation of NA+ and water channels in the collecting duct. Am J Transplant. 2005;5(6):1276-1285.

94. Lackovic J, Howitt J, Callaway JK, Silke J, Bartlett P, Tan SS. Differential regulation of Nedd4 ubiquitin ligases and their adaptor protein Ndfip1 in a rat model of ischemic stroke. Exp Neurol. 2012; 235(1):326-335. 
95. Sang Q, Kim MH, Kumar S, et al. Nedd4-WW domain-binding protein 5 (Ndfip1) is associated with neuronal survival after acute cortical brain injury. J Neurosci. 2006;26(27):7234-7244.

96. Putz U, Howitt J, Lackovic J, et al. Nedd4 family-interacting protein 1 (Ndfip1) is required for the exosomal secretion of Nedd4 family proteins. J Biol Chem. 2008;283(47):32621-32627.

97. Steinberg GR, O’Neill HM, Dzamko NL, et al. Whole body deletion of AMP-activated protein kinase \{beta 2 reduces muscle AMPK activity and exercise capacity. J Biol Chem. 2010;285(48):37198-37209.

98. Bair AM, Thippegowda PB, Freichel M, et al. Ca2+ entry via TRPC channels is necessary for thrombin-induced NF-kappaB activation in endothelial cells through AMP-activated protein kinase and protein kinase Cdelta. J Biol Chem. 2009;284(1):563-574.

99. Wu WN, Wu PF, Zhou J, et al. Orexin-A activates hypothalamic AMP-activated protein kinase signaling through a $\mathrm{Ca}(2)(+)$-dependent mechanism involving voltage-gated L-type calcium channel. Mol Pharmacol. 2013;84(6):876-887.

100. Alesutan I, Föller M, Sopjani M, et al. Inhibition of the heterotetrameric $\mathrm{K}+$ channel KCNQ1/KCNE1 by the AMP-activated protein kinase Mol Membr Biol. 2011;28(2):79-89.

101. Andersen MN, Krzystanek K, Jespersen T, Olesen SP, Rasmussen HB. AMP-activated protein kinase downregulates Kv7.1 cell surface expression. Traffic. 2012;13(1):143-156.

102. Mia S, Munoz C, Pakladok T, et al. Downregulation of Kv1.5 $\mathrm{K}$ channels by the AMP-activated protein kinase. Cell Physiol Biochem. 2012;30(4):1039-1050.

103. Bhalla V, Oyster NM, Fitch AC, et al. AMP-activated kinase inhibits the epithelial $\mathrm{Na}+$ channel through functional regulation of the ubiquitin ligase Nedd4-2. J Biol Chem. 2006;281(36):26159-26169.

104. Catterall WA. Sodium channels, inherited epilepsy, and antiepileptic drugs. Annu Rev Pharmacol Toxicol. 2014;54:317-338.

105. Heron SE, Crossland KM, Andermann E, et al. Sodium-channel defects in benign familial neonatal-infantile seizures. Lancet. 2002;360(9336): 851-852.

106. Ogiwara I, Miyamoto H, Morita N, et al. Nav1.1 localizes to axons of parvalbumin-positive inhibitory interneurons: a circuit basis for epileptic seizures in mice carrying an Scn1a gene mutation. JNeurosci. 2007;27(22):5903-5914.

107. Yu FH, Mantegazza M, Westenbroek RE, et al. Reduced sodium current in GABAergic interneurons in a mouse model of severe myoclonic epilepsy in infancy. Nat Neurosci. 2006;9(9):1142-1149.

108. Chiron C. Current therapeutic procedures in Dravet syndrome. Dev Med Child Neurol. 2011;53(Suppl 2):16-18.

109. Waxman SG, Merkies IS, Gerrits MM, et al. Sodium channel genes in pain-related disorders: phenotype-genotype associations and recommendations for clinical use. Lancet Neurol. 2014;13(11): 1152-1160.

110. Catterall WA, Dib-Hajj S, Meisler MH, Pietrobon D. Inherited neuronal ion channelopathies: new windows on complex neurological diseases. J Neurosci. 2008;28(46):11768-11777.

111. Cox JJ, Reimann F, Nicholas AK, et al. An SCN9A channelopathy causes congenital inability to experience pain. Nature. 2006;444(7121): 894-898.

112. Meisler MH, Kearney JA. Sodium channel mutations in epilepsy and other neurological disorders. J Clin Invest. 2005;115(8):2010-2017.
113. Wang J, Ou SW, Wang YJ, Kameyama M, Kameyama A, Zong ZH. Analysis of four novel variants of Nav1.5/SCN5A cloned from the brain. Neurosci Res. 2009;64(4):339-347.

114. Tfelt-Hansen J, Winkel BG, Grunnet M, Jespersen T. Inherited cardiac diseases caused by mutations in the Nav1.5 sodium channel. J Cardiovasc Electrophysiol. 2010;21(1):107-115.

115. Moss AJ, Goldenberg I. Importance of knowing the genotype and the specific mutation when managing patients with long QT syndrome Circ Arrhythm Electrophysiol. 2008;1(3):213-226; discussion 226.

116. Moss AJ, Windle JR, Hall WJ, et al. Safety and efficacy of flecainide in subjects with Long QT-3 syndrome (DeltaKPQ mutation): a randomized, double-blind, placebo-controlled clinical trial. Ann Noninvasive Electrocardiol. 2005;10(4 Supp1):59-66.

117. Maljevic S, WuttkeTV, Lerche H. Nervous system KV7 disorders: breakdown of a subthreshold brake. J Physiol. 2008;586(7):1791-1801.

118. Weckhuysen S, Mandelstam S, Suls A, et al. KCNQ2 encephalopathy: emerging phenotype of a neonatal epileptic encephalopathy. Ann Neurol. 2012;71(1):15-25.

119. Main MJ, Cryan JE, Dupere JR, Cox B, Clare JJ, Burbidge SA Modulation of KCNQ2/3 potassium channels by the novel anticonvulsant retigabine. Mol Pharmacol. 2000;58(2):253-262.

120. Otto JF, Kimball MM, Wilcox KS. Effects of the anticonvulsant retigabine on cultured cortical neurons: changes in electroresponsive properties and synaptic transmission. Mol Pharmacol. 2002;61(4) 921-927.

121. Yue C, Yaari Y. KCNQ/M channels control spike afterdepolarization and burst generation in hippocampal neurons. J Neurosci. 2004;24(19): 4614-4624.

122. Lehmann-Horn F, Mailander V, Heine R, George AL. Myotonia levior is a chloride channel disorder. Hum Mol Genet. 1995;4(8):1397-1402.

123. Depienne C, Bugiani M, Dupuits C, et al. Brain white matter oedema due to $\mathrm{ClC}-2$ chloride channel deficiency: an observational analytical study. Lancet Neurol. 2013;12(7):659-668.

124. Nozu K, Inagaki T, Fu XJ, et al. Molecular analysis of digenic inheritance in Bartter syndrome with sensorineural deafness. J Med Genet. 2008;45(3):182-186.

125. Schlingmann KP, Konrad M, Jeck N, et al. Salt wasting and deafness resulting from mutations in two chloride channels. $N$ Engl $J$ Med. 2004;350(13):1314-1319.

126. Fisher SE, Black GC, Lloyd SE, et al. Isolation and partial characterization of a chloride channel gene which is expressed in kidney and is a candidate for Dent's disease (an X-linked hereditary nephrolithiasis). Hum Mol Genet. 1994;3(11):2053-2059.

127. Wrong OM, Norden AG, Feest TG. Dent's disease; a familial proximal renal tubular syndrome with low-molecular-weight proteinuria, hypercalciuria, nephrocalcinosis, metabolic bone disease, progressive renal failure and a marked male predominance. QJM. 1994;87(8): 473-493.

128. Sekine T, Komoda F, Miura K, et al. Japanese Dent disease has a wider clinical spectrum than dent disease in Europe/USA: genetic and clinical studies of 86 unrelated patients with low-molecular-weight proteinuria. Nephrol Dial Transplant. 2014;29(2):376-384.
Journal of Receptor, Ligand and Channel Research

\section{Publish your work in this journal}

The Journal of Receptor, Ligand and Channel Research is an international, peer reviewed, open access, online journal. The journal welcomes laboratory and clinical findings in the fields of biological receptors, ligands, channel and signal transduction research including: receptors and signaling, ligands; transporters, pores and channels; binding and activation; receptor

\section{Dovepress}

regulation; role of receptors in diseases and their treatment; molecular basis of membrane structure and functions; molecular models of membranes. The manuscript management system is completely online and includes a very quick and fair peer-review system. Visit http://www.dovepress.com/ testimonials.php to read real quotes from published authors. 